\title{
The increase in domestic violence in Brazil from 2009-2014
}

\author{
O aumento da violência doméstica no Brasil, 2009-2014
}

Nádia Cristina Pinheiro Rodrigues ${ }^{1}$

Gisele O'Dwyer ${ }^{1}$

Mônica Kramer de Noronha Andrade ${ }^{1}$

Matthew Brian Flynn ${ }^{2}$

Denise Leite Maia Monteiro ${ }^{3}$

Valéria Teresa Saraiva Lino ${ }^{1}$

${ }^{1}$ Escola Nacional de Saúde Pública, Fiocruz. R. Leopoldo Bulhões 1480,

Manguinhos. 21041-210

Rio de Janeiro RJ Brasil. nadiacristinapr@gmail.com

${ }^{2}$ College of Liberal Arts and Sciences \& Center for International Studies, Georgia Southern

University. Statesboro GA EUA.

${ }^{3}$ Faculdade de Ciências

Médicas Universidade do

Estado do Rio de Janeiro.

Rio de Janeiro RJ Brasil.
Abstract In recent decades, the rise violent phenomena in Brazil has reached epidemic proportions. However, the prevalence of domestic violence (DV) across different states in the country is not well established. The objective of this study was to describe the distribution of DV across Brazilian states from 2009 to 2014. An ecological study based on spatial analysis techniques was performed using Brazilian states as geographical units of analysis. A multilevel Poisson model was used to explain the risk of DV in Brazil according to age, sex, period (fixed effects), the Human Developing Index, and the victim's residence state (random effects). The overall average rate of DV almost tripled from 2009-2010 to 2013-2014. The rate of DV in Brazil in the 2013-2014 period was 3.52 times greater than the 2009-2010 period. The risk of DV in men was $74 \%$ lower than in women. The increase of DV against women during period under study occurred mainly in the Southeast, South, and Midwest. DV was more frequent in adolescence and adulthood. DV is gradually increasing in recent years in Brazil. More legislation and government programs are needed to combat the growth of violence in society.

Key words Domestic violence, Spatial analysis, Epidemiology, Multilevel analysis
Resumo Nas últimas décadas houve um aumento epidêmico da ocorrência de fenômenos de violência no Brasil. Entretanto, a distribuição do padrão de violência doméstica (VD) nos diferentes estados ainda não está bem estabelecida. $O$ objetivo deste estudo foi descrever a distribuição de VD entre os estados brasileiros de 2009 a 2014. Estudo ecológico utilizando-se técnicas de análise espacial. Os estados foram utilizados como unidades de análise. Modelo de regressão multinível de Poisson foi utilizado para explicar o risco de VD segundo idade, sexo, período (fatores fixos), Índice de Desenvolvimento Humano e estado de residência (efeitos aleatórios). As taxas médias gerais de notificações de VD quase triplicaram de 20092010 para 2013-2014. A taxa de VD no Brasil em 2013-2014 foi 3.52 vezes maior do que em 20092010. O risco de VD em homens foi $74 \%$ menor do que nas mulheres. O aumento da violência doméstica nas mulheres ao longo do tempo ocorreu principalmente no sudeste, sul e centro-oeste. A $V D$ foi mais frequente em adolescentes e na fase adulta. A VD tem aumentado gradativamente nos últimos anos. O governo brasileiro ainda precisa avançar em termos de legislação e planos de ação, no intuito de combater o crescente problema da violência.

Palavras-chave Violência doméstica, Análise espacial, Epidemiologia, Análise multinível 


\section{Background}

In recent decades the increase in violent phenomena in some communities has reached epidemic levels ${ }^{1-3}$; however, in some developed countries, there has also been a decline of violence ${ }^{4,5}$. Sexual violence, either by intimate partners or not, is widespread, mainly affecting women worldwide $^{6-8}$. In Brazil, as in other countries, most violent episodes are related to alcohol abuse, illicit drug use, and access to weapons ${ }^{9,10}$. Not only women, but also children and elderly, are most at risk of being domestic violence (DV) victims. Among studies of the elderly, the disabled or dependents tend to be the victims $s^{11,12}$.

In Brazil, after the feminist movement (from 1960 to 1980), the number of DV prosecutions had increased ${ }^{9}$. However, only at the end of 2006 did Brazil pass the Maria da Penha Law, which provides legal protections for $\mathrm{DV}^{13}$. The law represented an important achievement for women and a significant advance on previous Brazilian legislation for combatting domestic and family violence against women ${ }^{14}$.

Although legislation concerning violence improved, Brazil still ranks seventh in world with the most female homicides. About 4,465 female homicides occurred in 2010 in Brazil ${ }^{15}$. Given Brazil's size and socio-cultural diversity, there are also significant regional differences in the distribution of violence across the country ${ }^{16}$. However, few studies have analyzed the distribution and variation of DV throughout the country ${ }^{17}$.

DV has a significant impact on morbidity. It affects not only victims but also their families and the rest of society ${ }^{6}$. National data show that people who have suffered DV are at greater risk of physical and psychological health problems than the general population, significantly impacting healthcare spending. DV is also associated with absenteeism at work and school ${ }^{6,18}$. Despite DV-associated problems, our knowledge about the distribution of DV is lacking. Therefore, the objective of this study is to describe the distribution of reports of physical violence at home in Brazilian states between 2009 and 2014, according to age, sex, period, and Human Developing Index (HDI).

\section{Methods}

This ecological study used spatial analysis techniques to describe the distribution of DV across the country.
Brazil, the largest country in South America with a population of over 200 million people (2015), includes a wide range of socioeconomic diversity. The HDI in the Southeast, South and Midwest regions of the country varies around $0.75-0.76$, while in the poorer North and Northeast the figure lies between 0.66-0.67. Brazil is divided into 26 states, in addition of the Federal District. These states are located in five different regions: the Southeast (four states), the South (three states), the Midwest (three states and the Distrito Federal), the North (seven states) and the Northeast (nine states).

DV includes various forms of interpersonal violence that occur in the family environment, which can be practiced by aggressors with marriage ties, kinship connections, emotional bonds, or domestic power relationships ${ }^{19}$. Physical DV refers to violent acts involving the intentional use of physical force with the aim to hurt, injure, cause pain and suffering, or eliminate the per$\operatorname{son}^{18}$. The variables included in this study are the following:

Outcome variables: physical DV. Only the reported cases of physical DV occurring in the home were used according to residence. We excluded the cases of self-violence, acts of violence by police, employers, persons with institutional link, and by unknown persons.

Explanatory variables: residence state, HDI, sex (male and female), two-year periods (20092010, 2011-2012 and 2013-2014) and age group $(<10,10-19,20-59$ and $\geq 60$ years old $)$.

\section{Data sources}

Demographic data were obtained from the 2010 population census and inter-census projections of the Brazilian Institute of Geography and Statistics (IBGE) ${ }^{20}$. Information about the number of reported victims of DV by state, sex, age group and two-year period were obtained from the Information System for Notifiable Diseases $\left(\right.$ SINAN) ${ }^{21}$. SINAN data are collected from notification forms of violence completed at health units.

The DV rates per 100,000 inhabitants were calculated for each geographic unit by sex, age group, and period.

We prepared thematic maps using a georeferenced mesh of Brazil's states (shapefile file available from the "Brazilian Institute of Geography and Statistic" website $)^{20}$. 


\section{Statistical methods}

The thematic maps, using Brazil's states as geographical units of analysis, depict sex (one for males and another for females), period, and age. A bar chart used in conjunction with the thematic maps illustrates the distribution of DV by age group and two-year period.

A multivariate Poisson regression model explains the risk of DV in Brazil ${ }^{22}$. Factors included in the model were sex, period, age group (fixed effects), state and HDI (random effects).

Model specification:

$$
\begin{aligned}
& Y \sim \text { Poisson }(\lambda) \\
& \log (\mu \text { cases })=\alpha+\beta_{1}{ }^{*} \text { sex }+\beta_{2}{ }^{*} \text { age group } \\
& +\beta_{3}{ }^{*} \text { period }+ \text { offset }(\log (\text { population })) \\
& +U_{\text {state }}+U_{H D I}
\end{aligned}
$$

where, $\mathrm{U}_{\text {state }}+\mathrm{U}_{\mathrm{HDI}}$ are random effects.
Graphical models and maps were used to present the results. All analyses were performed with TerraView (version 4.2.2.) and the package lme4 of R-Project (version 3.2.2) software.

\section{Results}

The overall average rate of DV reports almost tripled from 2009-2010 to 2013-2014, increasing from $6.40 / 100,000$ to $18.19 / 100,000$. The average rate of DV against women in the period was greater than triple than that reported by men. While in men, the overall average rates ranged from $3.26 / 100,000$ to $7.68 / 100,000$ from 20092010 to $2013-2014$, in women, the rates ranged from $9.54 / 100,000$ to $28.69 / 100,000$ during the same period. DV rates gradually increased in the period for both males and females in almost all Brazilian regions (Figure 1).

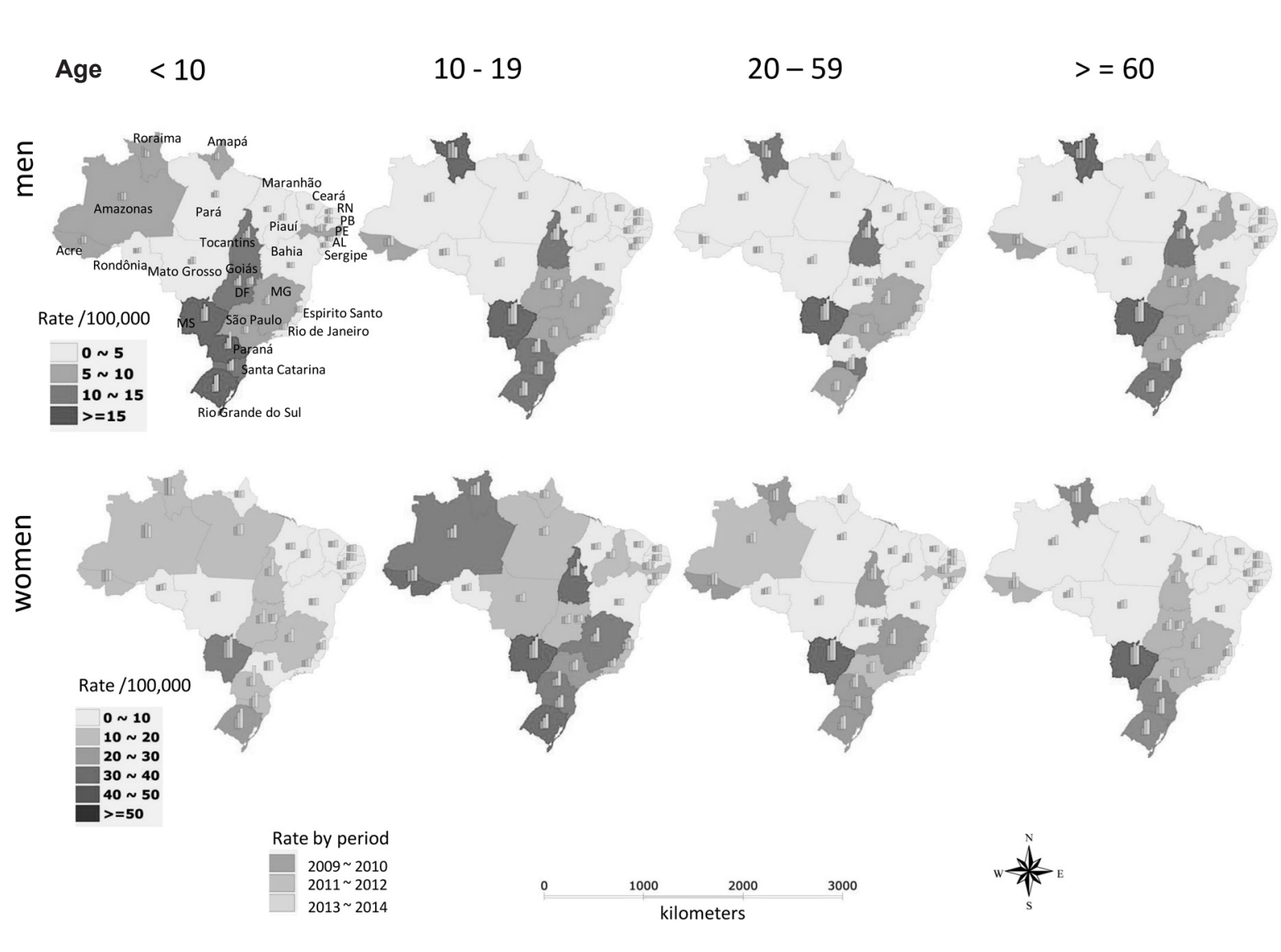

Figure 1. Distribution of domestic violence rates in Brazil by period, sex and age (2009-2014) 
In the 2009-2010 period, male DV rates reached values higher than 19.5/100,000 in the Midwest (Mato Grosso do Sul), in border areas with Paraguay and Bolivia, and in the North (Roraima), along the border areas with Venezuela and Guyana. In the 2011-2012 period, there was a gradual increase of male rates in the South, Southeast, and North. In the last period, 2013-2014, Mato Grosso do Sul in the Midwest, Tocantins in the North, Minas Gerais in the Southeast, and Santa Catarina in the South stood out amongst Brazilian states reporting the highest rates of male DV at 15/100,000 or above (Figure 2).

In women, only Mato Grosso do Sul in the Midwest showed a rate higher than 50/100,000 in 2009-2010 period. In general, DV rates in women also grew gradually during the period under study. By 2013-2014, four states showed DV rates higher than 50/100,000 (Tocantins, Minas Gerais, Rio Grande do Sul and Paraná) (Figure 2).

Male DV rates of the youngest and oldest age groups (younger than 10 years old and older than 59 years old) were remarkable amongst the Midwest states, while only the youngest age group appear significantly higher in the South. In the other areas, the male rates were reasonably homogeneous amongst the different age groups (Figure 1). Figure 2 indicates that the lowest male rate was the 20-59 age group. In contrast, DV rates of women aged 20-59 and also those aged 10-19 years were the highest in majority of Brazilian areas (Figure 1 and 2).

The rate of DV in Brazil in the 2011-2012 and 2013-2014 periods was 2.69 and 3.52 times greater than in the 2009-2010 period, respectively, independent of sex, age, HDI and state of residence.

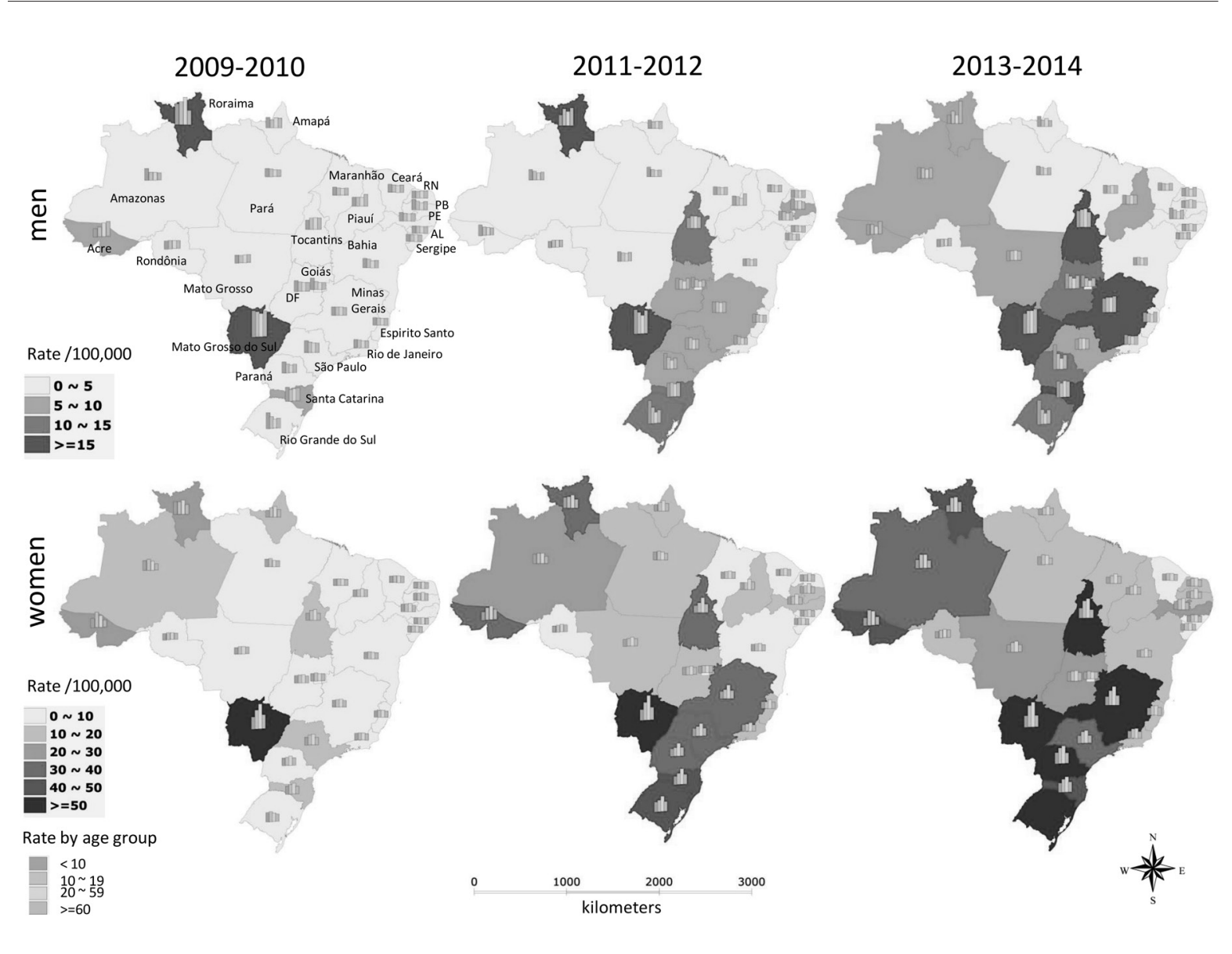

Figure 2. Distribution of domestic violence rates in Brazil by age, sex and period (2009-2014)

$\mathrm{RN}=$ Rio Grande do Norte; $\mathrm{PB}=$ Paraíba; $\mathrm{PE}=$ Pernambuco $; \mathrm{AL}=$ Alagoas; $\mathrm{DF}=$ Federal District $\mathrm{MG}=$ Minas Gerais. 
The risk of DV in men was 3.85 times (74\%) lower than in women, independent of period, age, HDI and state of residence. The highest risk of DV occurred in the 20-to-59 age group (Adjusted Relative Risk $(\mathrm{RR})=1.74$, reference age group: < 10 years). Compared to the younger age group, the risk of violence falls $21 \%$ in people aged 60 or more, but increases 56\% for those aged 10-19 years, independent of sex, period, HDI and state of residence (Table 1).

\section{Discussion}

Violence in the family environment accounts for a significant proportion of the morbidity and mortality rates in Brazil ${ }^{23}$. The rate of DV reports increased gradually from 2009 to 2014 in Brazil.

From 2009 to 2014, DV notifications of female victims quadrupled those of male victims: 124,805 and 32,027, respectively. Our findings indicated that the risk of DV is 3.84 times greater in women. According to the World Health Organization (WHO), in last three decades there was an increase of $230 \%$ in the number of violent deaths of females in Brazil24.

We found that adolescents and adults (10-19 and 20-59 years old) are the age groups at risk for DV. Violence against adolescents and young adults is an important cause of early mortality and reduced life quality ${ }^{25}$. In 1990, the Brazilian Statute of the Child and Adolescent was created in order to protect individuals under 18 years $^{26}$, and in 2007 new legislation focused on educating young people about the subject of DV in the public school system ${ }^{13}$. Another Brazilian initiative was the implementation in 2006 of the Surveillance System for Violence and Accidents (VIVA) for gathering data about the magnitude of violence and accidents in Brazilian public health ${ }^{27}$. VIVA provides continuous monitoring of DV, in addition to other forms of violence ${ }^{27}$.

Despite these initiatives, the average rate of violence against adolescents is still growing (7/100,000 in 2009-2010; 15/100,000 in 20112012; and 19/100,000 in 2013-2014). For adult victims (20-59 years old) the situation is no different; our findings indicate rising incidence rates for this age group (7/100,000 in 2009-2010; $16 / 100,000$ in $2011-2012 ; 22 / 100,000$ in 20132014).

The risk of DV in children (younger than 10 years old) also increased during the period under study (5/100,000 in 2009-2010; 10/100,000 in 2011-2012; and 11/100,000 in 2013-2014). Physical aggression against children is still a common practice $(67.4 \%)$ in Brazil $^{28}$. Violent injuries to children also stand out in medical emergencies $(55 \%)^{28}$. A study carried out at public health services in Rio de Janeiro/Brazil (2001) indicated that about $10 \%$ to $25 \%$ of parents commit minor physical violence against children ${ }^{29}$. In an urban center located in southeastern Brazil (2005), a study detected that about $44 \%$ of students at public schools had already experienced physically aggression in their homes ${ }^{30}$.

For DV against older people (older than 59 years old), our findings indicated that the risk of DV almost doubled from 2009-2010 to 20132014. The average rate of DV reports ranged from $6 / 100,000$ to $11 / 100,000$ over the period. One recent Brazilian study indicated that about $10 \%$ of

Table 1. Sex, age and period effects on the rate of domestic violence over 2009-2014.

\begin{tabular}{lccccc}
\hline \multicolumn{1}{c}{ Fix effects } & Categories & RR & \multicolumn{2}{c}{$\mathbf{9 5 \%}$ CI } & p-value \\
\hline $\begin{array}{l}\text { Sex } \\
\text { reference - female }\end{array}$ & Male & 0.26 & 0.26 & 0.27 & 0.0001 \\
& & & & & \\
Age group & $10-19$ & 1.56 & 1.53 & 1.59 & 0.0001 \\
reference - $<$ 10 years old & $20-59$ & 1.74 & 1.71 & 1.77 & 0.0001 \\
& $\geq 60$ & 0.79 & 0.77 & 0.81 & 0.0001 \\
Period & $2011-2012$ & 2.69 & 2.65 & 2.73 & 0.0001 \\
reference - 2009-2010 & $2013-2014$ & 3.58 & 3.52 & 3.63 & 0.0001 \\
\hline
\end{tabular}

*Multilevel Poisson model was used to estimate the rate ratio of domestic violence in Brazil. The factors included in the model were: 1 ) Fix effects: sex, age group and period; 2) Random effects: state and Human Development Index. 
the elderly are victims of $\mathrm{DV}^{12}$. The risk of DV amongst the elderly seems to be greater for those who are physically dependent and mentally $\mathrm{ill}^{11}$.

Although research findings represent official data, some limitations need to be considered. The increase of DV reports during the study period could reflect new policies focused on women that were implemented in 2000s. The passage of the Maria da Penha Law (7 August 2006) has contributed to an upsurge in reports of violence to health services ${ }^{13,14}$. However, several factors still contributed to an underestimation of the real context of violence in Brazil. Reporting is compulsory only for children, adolescents, elderly and female adults ${ }^{26,31-33}$, but not for male adults, thus reducing the validity of indicators for adult male DV. Surveillance workers also frequently disregard the need to notify. Notifications in basic health units are less frequent due to fear of aggressor's revenge by both the victim and his acquaintances as well as health professionals. Most patients do not recognize violence as a responsibility of the health care system, so they do not feel it necessary to report cases of aggression at public health facilities. Notification occurs mainly when the victim receives hospital care after a DV event, so it is possible that the reports reflect mostly se- vere cases of physical aggressions and those most likely reported to the police. Finally, the lack of privacy in public health services also discourages victims from filing reports ${ }^{34-37}$. All the factors mentioned above can contribute to underestimates of DV to varying degrees according to the specific contexts of each state.

\section{Conclusions}

Violence occurring in the family environment accounts for significant morbidity and psychological distress. Public policies focusing on violence have sought to curb its use and promote a culture of peace ${ }^{38}$. Numerous governments have signed international agreements recognizing the need to develop broad multi-sectorial approaches to prevent and minimize violence, especially against women. Despite these initiatives and many others, more efforts are needed to combat the growing problem of violence in Brazil. Institutional and legal reforms still need to be implemented in order to reduce $\mathrm{DV}^{39-41}$. Our findings illustrate the magnitude of domestic violence across different states in Brazil, which could be an important base for future research and policies.

\section{Collaborations}

NCP Rodrigues conceived of the study, participated in its design and coordination, helped to draft the manuscript and performed the statistical analysis. All authors helped to draft the manuscript, read and approved the final manuscript. 


\section{References}

1. Muza GM. The abused and neglected child. J Pediatr (Rio J) 1994; 70(1):56-60.

2. Cengiz H, Kanawati A, Yildiz S, Suzen S, Tombul T. Domestic violence against pregnant women: A prospective study in a metropolitan city, Istanbul. J Turk Ger Gynecol Assoc 2014; 15(2):74-77.

3. Miller E, Breslau J, Petukhova M, Fayyad J, Green JG, Kola L, Seedat S, Stein DJ, Tsang A, Viana MC, Andrade LH, Demyttenaere K, de Girolamo G, Haro JM, Hu C, Karam EG, Kovess-Masfety V, Tomov T, Kessler RC. Premarital mental disorders and physical violence in marriage: cross-national study of married couples. $\mathrm{Br}$ J Psychiatry 2011; 199(4):330-337.

4. Denton J, Newton AW, Vandeven AM. Update on child maltreatment: toward refining the evidence base. Curr Opin Pediatr 2011; 23(2):240-248.

5. Parker KF, Stansfield R. The Changing Urban Landscape: Interconnections Between Racial/Ethnic Segregation and Exposure in the Study of Race-Specific Violence Over Time. Am J Public Health 2015, 105(9):1796-1805.

6. World Health Organization (WHO). World report on violence and health 2002. [cited 2016 Apr 4]. Available from: http://www.who.int/violence_injury_prevention /violence/world_report/en/full_en.pdf?ua=1.

7. Ho IK, Dinh KT, Smith SA. Intimate partner violence and physical health outcomes among Southeast Asian American women. J Health Psychol 2015.

8. Baird K. Women's lived experiences of domestic violence during pregnancy (1). The practising midwife 2015; 18(3):27-31.

9. Oliveira ER. Family and domestic violence against women: a subjugation scenario of females. Revista do Laboratório de Estudos da Violência da UNESP [Internet]. 2014 11/11/2014. [cited 2016 Apr 4]. Available from: http://www2.marilia.unesp.br/revistas/index.php /levs/article/viewFile/2283/1880

10. Ali AA, Yassin K, Omer R. Domestic violence against women in Eastern Sudan. BMC Public Health 2014; 14(1):1136.

11. Khalifeh H, Howard LM, Osborn D, Moran P, Johnson S. Violence against people with disability in England and Wales: findings from a national cross-sectional survey. PloS one 2013; 8(2):e55952.

12. Moraes CL, Apratto Júnior PC, Reichenheim ME. Breaking silence and its barriers: a household survey on domestic violence against the elderly within the scope of a Family Health Program in Niterói, Rio de Janeiro State, Brazil. Cad Saude Publica 2008; 24(10):22892300.

13. Brasil. Lei no 11.340 , de 7 de agosto de 2006. Cria mecanismos para coibir a violência doméstica e familiar contra a mulher, nos termos do $\$ 80$ do art. 226 da Constituição Federal, da Convenção sobre a Eliminação de Todas as Formas de Discriminação contra as Mulheres e da Convenção Interamericana para Prevenir, Punir e Erradicar a Violência contra a Mulher; dispõe sobre a criação dos Juizados de Violência Doméstica e Familiar contra a Mulher; altera o Código de Processo Penal, o Código Penal e a Lei de Execução Penal; e dá outras providências. Diário Oficial da União 2006; 8 ago.
14. Alves ES, Oliveira DL, Maffacciolli R. Repercussions of Maria da Penha law on addressing domestic violence in Porto Alegre. Rev Gaucha Enferm 2012; 33(3):141-147.

15. Waiselfisz JJ. Violence Map 2012. The new profile of homicidal violence in Brazil. São Paulo: Instituto Sangari; 2011.

16. Reichenheim ME, Souza ER, Moraes CL, Mello Jorge $\mathrm{MH}$, Silva CM, Souza Minayo MC. Violence and injuries in Brazil: the effect, progress made, and challenges ahead. Lancet 2011; 377(9781):1962-1975.

17. Lucena KD, Silva AT, Moraes RM, Silva CC, Bezerra IM. Spatial analysis of domestic violence against women from 2002 to 2005 in João Pessoa, Paraíba State, Brazil. Cad Saude Publica 2012; 28(6):1111-1121.

18. Brazilian Health Ministry. Instruction for filling the notification plug/investigation of domestic, sexual and/or other violence. Brasília: Brazilian Health Ministry; 2009.

19. Njaine K, Assis SG, Constantino P. Impact of Violence on Health. Rio de Janeiro: Editora Fiocruz; 2009.

20. Instituto Brasileiro de Geografia e Estatística (IBGE). Rio de Janeiro, Brazil 2014. [cited 2016 Apr 4]. Available from: http://www.ibge.gov.br/home/mapa_site/ mapa_site.php\#geociencias.

21. Brasil. Ministério da Saúde (MS). Sistema de Informação de Agravos de Notificação - SINAN Brasília, Brazil 2014. [cited 2014 Nov 9]. Available from: http:// dtr2004.saude.gov.br/sinanweb/index.php.

22. Gelman A, Hill J. Data Analysis Using Regression and Multilevel/Hierarchical Models. Cambridge: Cambridge University Press; 2006.

23. Minayo MCS. Social Violence from a Public Health Perspective. Cad Saude Publica 1994; 10(Supl.):S7-S18.

24. World Health Organization (WHO). Along 30 years, the number of murdered women in Brazil increased 230\%. Brasília: WHO; 2014.

25. Deslandes SF. Care of children and adolescents suffering domestic violence: analysis of a service. Cad Saude Publica 1994; 10(Supl.):S177-S87.

26. Brasil. Lei no 8069, de 13 de julho de 1990. Dispõe sobre o Estatuto da Criança e do Adolescente e dá outras providências. Diário Oficial da União 1990; 27 set.

27. Brazilian Health Ministry. Viva: surveillance violence and accidents, 2006 and 2007. Brasília: Brazilian Health Ministry; 2009.

28. Mascarenhas MD, Malta DC, Silva MM, Lima CM, Carvalho MG, Oliveira VL. Violence against children: revealing the characteristics of emergency treatment, Brazil, 2006 and 2007. Cad Saude Publica 2010; 26(2):347-357.

29. Moura AT, Reichenheim ME. Are we really detecting violence in families of children visiting our health services? The experience of a public health service in Rio de Janeiro, Brazil. Cad Saude Publica 2005; 21(4):11241133.

30. Pinto LW, Goncalves de Assis S. Family and community violence of schoolchildren from the city of Sao Goncalo, Rio de Janeiro, Brazil. Rev Bras Epidemiol 2013; 16(2):288-300 
31. Brasil. Decreto no 5.099, de 3 de junho de 2004. Regulamenta a Lei no 10.778, de 24 de novembro de 2003, e institui os serviços de referência sentinela. Diário Oficial da União 2004; 4 jun.

32. Brasil. Lei $n^{\circ} 10.778$, de 24 de novembro de 2003. Estabelece a notificação compulsória, no território nacional, do caso de violência contra a mulher que for atendida em serviços de saúde públicos ou privados. Diário Oficial da União 2003; 25 nov.

33. Brasil. Lei no 10.741 , de 1 de outubro de 2003. Dispõe sobre o Estatuto do Idoso e dá outras providências. Diário Oficial da União 2003; 3 out.

34. Kiss LB, Schraiber LB. Social medical themes and the health intervention: violence against women in the professional's discourse. Cien Saude Colet 2011; 16(3):1943-1952.

35. Guedes RN, Fonseca RM, Egry EY. The evaluative limits and possibilities in the family health strategy for gender-based violence. Rev Esc Enferm USP 2013; 47(2):304-311.

36. Signorelli MC, Auad D, Pereira PP. Domestic violence against women and professional intervention in primary healthcare: an ethnographic study in Matinhos, Paraná State, Brazil. Cad Saude Publica 2013; 29(6):1230-1240.

37. Kind L, Orsini MeL, Nepomuceno V, Gonçalves L, Souza GA, Ferreira MF. Primary healthcare and underreporting and (in)visibility of violence against women. Cad Saude Publica 2013; 29(9):1805-1815.

38. Brasil. Ministério da Saúde (MS). BHM. [National Policy of Health Promotion] 2014. [cited 2016 Apr 4]. Available from: http://bvsms.saude.gov.br/bvs/publicacoes/politica_nacional_promocao_saude_3ed.pdf.

39. United Nations Human Rights (UNHR). Vienna Declaration and Programme of Action. World Conference on Human Rights; Vienna 1993. Washington: UN; 1993.

40. United Nations (UN). International Conference on Population and Development. International Conference on Population and Development; 11/04/2014; Cairo/Egypt. Washington: UN; 2014.

41. United Nations (UN). Action for Equality, Development and Peace Fourth World Conference on Women: Beijing/China 1995. Washington: UN; 1995.

Artigo apresentado em 04/11/2015

Aprovado em 13/04/2016

Versão final apresentada em 15/04/2016 